\title{
An Exploration of English Language Teachers' Strategies for Disciplining Unauthorized Behavior in Iranian Public and Private Language Schools
}

\author{
Marjan Vosough \\ English Department \\ Sabzevar Branch, Islamic Azad University, Sabzevar Iran \\ Zohreh Nafissi \\ English Department \\ Al-Zahra University, Tehran, Iran \\ Email:mvosoughee@gmail.com,znafisi@yahoo.com
}

\begin{abstract}
In this article, an attempt was made to explore English language teachers' strategies for disciplining unauthorized behavior (misbehavior) in public high schools and private language institutes. To this end, two sets of general and specific teacher strategies for disciplining misbehavior were surveyed in two successive stages. First, American Teacher Strategies Questionnaire from the Incredible Years Programs (IYP) incorporation (2012) was examined to decide on the most appropriate teacher techniques for general Class Management (CM) scheme; secondly, teacher interview logs were used to decide on the specific CM strategies, which were characteristic of language classes. Then, a researcher-developed questionnaire with a five-point Likert scale was constructed and distributed among some fifty-five Iranian teachers from public high schools and private language institutes in four large cities in Tehran, Isfahan, and Khorasan Razavi Provinces, and their responses were analyzed using Multinomial Logistic Regression method. The findings showed that only seven strategies could significantly differentiate language teachers' disciplining mannerism; three strategies in general $\mathrm{CM}$ and four strategies in specific $\mathrm{CM}$ for a language class were then interpreted. Finally, implications for discipline matters in formal and informal settings were critically discussed.
\end{abstract}

Keywords: Class Management (CM), Misbehavior, Teacher Strategy, Private schools, Public schools.

\section{INTRODUCTION}

Classroom Management (CM) in language learning contexts seems to be one of the under-explored areas of research in Applied Linguistics (AL) research. In its broadest sense, CM refers to virtually every aspect of interaction and activity that may occur in class (Markham, 1987). A closely related term to CM is School Discipline (SD), which means exhibiting self-respect and respect for others in the classroom (Kohut \& Range, 1979; cited in Markham, 1987). Based on this definition, it follows that SD is the 
practice of dealing with unruly, silent, and impolite students so that all are treated with respect by their teachers and vice versa. Oplatka and Atias (2007) define SD as realization of socially accepted and appropriate behavior.

This issue is no doubt of crucial concern for the novice language teacher; nevertheless, very few studies in AL, especially in Teaching English as a Foreign Language (EFL) context, can be found in the literature (Knopp, 1980; cited in Markham, 1987). There might be different underlying reasons for this paucity of research in this area. A quick internet search regarding this topic suggested this relative paucity of research in this area to be due to the great uncertainties that exist regarding how to deal with this delicate issue and the context-sensitivity of it. It may have been this multi-sidedness that may have warded off researchers from following this line of research. Soares (2007), for instance, believed that 'there is no hard and fast route for managing language classes concerning disciplinary issue'. Ur (1996) also looked at this subject from a General Educational (GE) perspective that neither teachers nor students have the same views on what constitutes acceptable or unacceptable behavior in classroom situation. For these reasons, this crucial subject might have been remained unexplored by the scholars in the field of English Language Teaching (ELT).

Regarding discipline matters, there are some arguments for the multidisciplinary nature of this topic. In fact, some scholars classify discipline under the expertise of GE specialists (Education Bureau, 2014). However, the underlying reason for the relevance of this issue to language classes can be, as Johnston (2008) in his book on values in ELT has argued, 'In some ways ELT is comparable but that in others it has its own peculiar moral landscape that must be explored and understood on its own terms' (p. x). Actually, a crucial point hidden in this assertion by Johnston is that various problems could arise during the class interactions in a language class that should be treated with special care and accordingly it should be negotiated with language experts rather than GE specialists. Regarding this argument, one must note that by 'problems' Johnston implied 'misbehavior' in classrooms. Misbehavior, in general, could be any disruptive or unauthorized behavior that might directly disturb language classroom's normal order. Accordingly, some instances might include tardiness, talking with classmates during lesson presentations by the teacher, inattention, etc. In a language class, however, misbehavior in the above sense as defined by Johnston might be of a different nature. In some instances, more characteristic of language classes could then include infringing on others' turns in group class discussions within group work, plagiarism in doing the given L2 assignments, coming to class without a textbook or the necessary materials, loud shouting in doing choral repetitions in lower level language courses, reacting aggressively to some cultural differences between the source and the target language, etc. (Johnston, 2008). Due to the context-specific nature of 'discipline' in Johnston's view and lack of much research on this topic in ELT, this study is in part aimed at filling in the gap that exists in this line of research.

In Iranian EFL situations, there are two educational settings where people have access to English language courses, namely, formal settings, in which language instruction begins at guidance school and continues until tertiary level at universities, and informal settings, where language learners have access to English instruction for further enhancing their knowledge and skills in using English for international 
communication purposes. By intuition, it is our assumption that in language institutes there is a general belief that the learners' interest and motivation to learn may predictably prevent them from trying to disturb the class atmosphere. This means that students that attend such classes are not likely to show any cases of unauthorized behavior. However, if we specify exactly what constitutes disruptive behavior in a language class, it is also the case that, in these informal settings, it is highly probable that such behavior is worthy of studying.

In formal settings like high schools and universities, since there is a diversity of learners from various social classes with different levels of motivation for learning along with diverse proficiency levels all attending the same class, it may be that some other sources of misbehavior in a language class might occur. For instance, the differences in the proficiency levels of the students in such classes may lead the lower proficiency level students to show disruptive behavior in order to be included in class discussions. It calls for the language teachers to make the best use of their pedagogical knowledge and skills to adopt certain standard strategies to predict and prevent such disruptive misbehavior from arising in their classes.

In this exploratory research, the authors have attempted to look at language teachers' strategies for managing their classes via a differential research design drawing on two diverse Iranian educational settings for English language teaching, namely public high schools and private language institutes. An attempt has been made to have an introspective view into the minds of the sampled teachers in the two settings regarding the proper strategies that they deemed essential in managing misbehavior in language class.

\section{BACKGROUND OF THE STUDY}

Regarding problems leading to disciplinary issues for language classes, some aspects such as class size (Butler, 2011), unauthorized use of first language by students (Kang, 2013), negative class participation (Soares, 2007), cultural mismatches (Lefstein, Trachtenberg-Maslaton, \& Pollak, 2017) were more eye-catching among others in the existing literature. Before proceeding to an exploration of strategies used by language teachers, it seemed essential to illuminate what was meant by misbehavior in English language teaching classes based on the recently conducted research.

As for disciplinary issues in ELT, recently, Butler (2011) explored class size effect for implementing Communicative Language Teaching (CLT) method in some Asian contexts. He found out that the group work and free movements that are required in CLT may lead to the students taking advantage and creating tension in the constrained language classes in Asian EFL contexts.

In a similar research, Kang (2013) considered disciplinary issues related to unauthorized use of the students' first language (L1, here Korean) and the English language, which had been rooted in some EFL Korean elementary school teaching practices. In his study, the low proficiency level of the teachers had led to their predominantly using Korean as the medium of instruction rather than the Target Language (TL). The teachers' explanation for their sporadic use of the TL was centered 
on the parents' opposition to frequent use of TL forms in the class. This, according to the teachers' contention, led to conflicts related to authority, which undermined the power and authority of the teachers. The incomprehensibility of the language used to conduct the class led to disruptive behavior by the students, which could not be dampened among overactive students. Some reasons related to geographical areas of teaching in less affluent areas also led the high proficiency level teachers in his study to support TL compared with L1 to discipline their students. In all, with regard to disturbing disciplinary issues in language classrooms more than one factor was found to be at work at the same time in Kang's (2013) study; they included socio-political, social, geographical, and economic factors, showing how closely disciplinary issues can be associated with other factors, both inside and outside language classrooms.

Regarding probable disciplinary problems that might occur in an EFL class, Soares (2007) investigated the issue through an action research among some $10 \mathrm{EFL}$ students in Rio de Janeiro, Brazil. In his study, he focused on how to minimize negative class participation. Soares first offered a good example of how to interpret a quiet student during group work activities in language discussions to be indicative of indiscipline on the part of that student or his/her disinterest in the topics chosen and codify that learner as unwilling to participate in class discussions and thus an indication of misbehavior. She conducted two experiments, one in 1995 and a follow up study some twelve years later. In her first study, Soares managed to devise a series of codes of conduct and brought them to the students' attention that those rules must be observed if they want to be accepted as positive learners. Before this stage, she sought students' views regarding the causes of their indiscipline in class through an anonymous questionnaire by which they shared their views with Soares as the teacher-researcher in the project. That project was very successful at bringing ease to managing the class, but her tactics did not work at all for her next project with a group of misbehaved students, who were a group of intimate friends attending a language institute. There were many conflicting views regarding such issues as the amount of first language (here Portuguese) use in class. In the end, she decided to make some changes in her strategies in controlling the class by allowing some sporadic uses of the learners' L1 so as to garner the undivided attention of the students in participating in class activities and to create an enjoyable environment conducive to learning.

In some studies, language scholars had mapped cultural mismatches over proper using of techniques by language teachers in order to prevent disciplinary issues through either 'teacher control or students' autonomy' (Dewey, 1938; cited in Lefstein, Trachtenberg-Maslaton, \& Pollak, 2017) in their classroom situation. In managing classroom talks, addressing some sensitive topics and complex behavior had been very challenging. Conspicuously, this meant from moral as well as religious aspects, both learners and teachers had to be cautious in their reactions so as not to annoy or offend anybody. By the same token, Western mannerism in managing life issues, such as love, friendship, food habits, etc. had to be cautiously approached by all language teachers.

In Iranian contexts as an EFL situation, however, we found very few studies on controlling language classes. In response to the dearth of research in language class discipline, Rahimi and Hosseini (2012) conducted a comprehensive study on this issue. Their results finally seemed to indicate that Iranian EFL teachers mostly used recognition/rewarding strategies in maintaining discipline in their classes rather than 
resorting to punishing strategies to maintain order in their classes. To eradicate disruptive behavior, both explicit and implicit tactics could typically be used by all teachers in general and language teachers in particular. In another study by Khodarahmi and Motallebi Nia (2014), EFL learners' perceptions of classroom discipline strategies were mapped on their willingness to communicate (WTC). The results showed that WTC inside the classroom was significantly related to the learners' perception of the discipline strategies that had been employed by their teachers.

Regarding the relationship between disciplinary issues and wider social matters at large, Margutti (2006) showed how explicit reproach in classroom discourse could in some cases turn into accusation, which, in his view, could have both moral and legal rings linked to it. In a more recent study, and along with his previous study, Margutti and Marsh (2011) through conversational analysis analytically examined how classroom interaction could shape student and teacher expectations. Reproach, corporal punishment, direct advice, and negative gestures were just some examples of tactics which had usually been used by teachers, and argued how, on moral accounts, this mannerism, if not routed through appropriate channels, could be destructive with students in sensitive ages, especially adolescents.

Teaching language classes with multi-proficiency-level students can be conducive to some misbehavior by students in secondary schools (Ashton, 2018). In language schools, on the other hand, this drawback is resolved by assigning language learners to appropriate proficiency-level classes via giving them placement tests.

\section{ADOPTED STRATEGIES FOR TREATING MISBEHAVIOR}

In language classes, sources of unauthorized behavior were thought by some scholars to have been mostly initiated from inappropriate strategies adopted by language teachers. Brown (2001a), for example, discussed how turn-taking among volunteering students who liked to participate in class discussions was problematic. According to Brown, even in situations where actively dedicated and intrinsically motivated students are more in number, as in language institutes, discipline problems are a case in point for a language teacher to take into account. Along similar lines, there was a substantial body of research on the effects of positive teacher strategies such as praise and appreciation, on the students' further progress. Trying to deal with unauthorized behavior via positive and negative strategies was believed to have differing outcomes. Positive strategies, such as praise, for instance, was believed to boost students' confidence and motivation in attaining success, while negative strategies such as reproach or corporal punishment, could lead to students' disappointment and educational setbacks (Cox \& Boyson, 1975; Dreikurs, Cassel, \& Ferguson, 2004; Kounin, 1970; Martin, 1977; Sun, 2015; Woolfolk Hoy \& Weinstein, 2006).

Adopting appropriate techniques was also found to be pertinent in language classes from task management angles. As an example, DorBremme (1990) in his study of a group of Italian primary school students attending an American class explicated how language use could decontextualize activities when the teacher did not employ appropriate techniques or strategies in transferring to another linguistic activity inside the class. 
In some studies, other sources of misbehavior had been associated with students' family structures having to do with their working parents, ineffective parental discipline and the dysfunctional families in general (Jinot, 2018). This can surely influence how and to what extent teachers should apply proper strategies for tackling the discipline problems in class.

Lewis, Romi, Qui and Katz (2008) investigated the positive effects of creating recognition and involvement techniques for instilling and maintaining disciplined behavior in class. In general, in the existing literature, adopting proper strategies for class management on disciplinary issues has been considered to be among the characteristics of effective teachers. For example, Molica and Nuessel (1997) outlined the characteristics of effective language teachers, which included maintaining class discipline as a very prominent feature among the other features for a teacher to be characterized as an effective teacher. In effect, this had been viewed in other studies too to be conducive to learning by students (Rose \& Gallup, 2004).

De Jong, Tartwijk, Wubbels, Veldman, and Verloop (2013) examined students and teachers' opinions regarding class discipline and what strategies they considered to be the most effective in instilling order in class. The final results obtained by multiple regression analysis showed that teachers' discipline strategies could be explained satisfactorily in terms of beliefs regarding control, including self-image, anticipated student responses, and pupil control orientation.

Glock and Kleen (2017) associated adopted strategies by effective teachers with students' gender status. By prospect, they stated that gender-specific biases as taken by teachers had to do with their views with male students being in the limelight that was consistently alighted with negative reactions as they called it 'boy crisis'.

Strack and Deutsch (2004), in their study, detailed implicit psychological tendencies of teachers (reflective vs. repulsive) as personality types, which were conductive in the kind of strategies being taken.

Brown (2007) prioritized the role of teachers on managing English language classes, which can lead to effective instruction. In the same line, Rahimi and Asadollahi (2012) attributed effective class management to the teaching styles that Iranian English language teachers utilized.

Due to the complex nature of classroom discourse, still there might be a multitude of factors that influence the type of strategies by teachers in general and language teacher in particular. In this study due to the paucity of research on the role of context- public and private- institutes, this issue was closely considered to check how it plays its role in the kind of strategies that language teachers adopted in Iranian English language teaching settings.

\section{OBJECTIVE OF THE STUDY}

In line with conducting research on teacher strategies in disciplining disruptive behavior by students, this issue was examined in various educational settings in Iran, including 
both public schools and private institutes. This study was conducted using informants' views analysis obtained via distributing questionnaires to collect information as to what specific strategies were the preferred strategies used by the language teachers involved in the two different settings mentioned above. The purpose of the study was to find out if there were any hidden or unknown strategies in addition to the 'standard' ones regarding discipline matters in class management (CM) adopted by teachers in educational settings, both public and private, in Iran.

The questions for our purposes in this study were:

1. Are English language teachers' strategies in disciplining disruptive behavior in private Iranian language institutes essentially different from those adopted by English language teachers in Iranian public high schools?

2. To what extent are English language teachers at two public and private Iranian institutions different concerning general CM strategies?

3. To what extent are English language teachers at two public and private Iranian institutions different concerning specific CM strategies?

\section{METHODOLOGY}

\section{Sampling}

The participants who contributed their time in responding to our questionnaire were a group of fifty-five English language teachers (Male: 11 and Female: 44) teaching in various Iranian private language institutes and public high schools randomly selected through stratified sampling tactics from three major Iranian provinces of Tehran, Isfahan, and Khorasan Razavi (Mashhad and Sabzevar) in Spring 2015. The teachers' average age was 30-35, with five to ten years of teaching experience. Table 1 displays the demographic information of the sampled participants in this study in terms of teaching experience and gender mapped on the teachers' school type (public and private).

Table 1: Cross Tabulation of the Participants' Demographic Information

\begin{tabular}{llcclc}
\hline School type & \multicolumn{3}{l}{ Teaching experience } & \multicolumn{2}{l}{ Gender } \\
\cline { 2 - 6 } & $5-10$ & $10-15$ & $15-20$ & Male & female \\
\hline Private & 23 & 13 & 4 & 2 & 38 \\
\hline Public & 4 & 6 & 5 & 9 & 6 \\
\hline
\end{tabular}

Those teachers who had teaching experience at both schools and private institutes were required to fill out two questionnaires, one for public and one for private school in tandem. This had been specified at the top line of the questionnaire, i.e. it had been explicitly explained that the questionnaire was concerned with which institution (public or private) they worked so in case they had both experience they were required to fill out the two questionnaires. 


\section{Instrumentation}

In order to elicit the intended strategies by the sampled language teachers for the purposes of this research, a researcher-developed questionnaire with Likert-type scale was produced (Appendix A) having twenty-two closed items along with one openended item that catered for any other strategy language teachers believed to be effective, but which to their view was missing in the questionnaire.

In constructing the items of the questionnaire related to our situation, first, we examined American Teacher Strategies Questionnaire released by the Incredible Years Programs incorporation (IYP, 2012) for deciding on the most appropriate teacher techniques for general CM which might be shared by GE principles, secondly, teacher interview $\operatorname{logs}$ were used to decide on the specific CM strategies, which were characteristic of language classes. American Teacher Strategies Questionnaire had been recommended by the American Psychological Association (APA) in critical evaluation of research designs on misconduct or misbehavior in classroom situations. All program materials for IYP are also accessible through www.incredibleyears.com.

Then, we developed a questionnaire with a five-point Likert scale ranging from 'strongly disagree' to 'strongly agree' and distributed it among some 66 Iranian teachers from public high schools and private language institutes. Eight questionnaires were discarded on the grounds of some items being left unanswered, perhaps due to the participants' time constraints. Subsequently, the remaining fifty-five completed questionnaires were analyzed in terms of the strategy types as recognized by the sampled language teachers.

In designing the questionnaire, we took utmost care to ensure that our instrument has high validity and reliability. For validity concerns, we used experts' opinions. Apart from the inspirations we drew from the IYP cited above, the interview logs were used with three Ph.D students of TEFL, one of whom was an experienced high school teacher. They were asked to review the whole questionnaire, and their points of view were used to make modifications in the developed questionnaire to a certain extent. The respondents were asked to give their thoughts and ideas on each item. After amending some items and including other essential strategies as decided by the recruited experts, the final version of the developed questionnaire included the teacher CM strategies (both general and specific) in both private language institutes and public high schools in Iranian contexts. It was arranged in two sections, namely A) General CM (thirteen items) and B) Specific CM (nine items) contexts.

For assessing the reliability of the questionnaire, measures of internal consistency were used. An attempt was thus made to estimate the reliability of the questionnaire using Cronbach's Alpha method, and the result showed an index value of $\alpha=0.697$, which was considered to be an acceptable index, though at just the threshold level, based on the guidelines of $(0.6 \leq \alpha<0.7)$ provided by George and Mallory (2003). According to Brown (2001b), however, the $\alpha$ value has to be interpreted in the light of both test length and the number of participants; thus, all other factors being held constant, Cronbach $\alpha$ value is usually higher for longer tests; so, the index for our data collection tool might have been related to the test length. 


\section{Data Analysis Procedures}

To reiterate the research purposes of this study, the authors aimed at examining English language teachers' strategies in dealing with disruptive behavior across two public and private Iranian institutions regarding both general and specific CM. To this end, the collected data from the distributed questionnaires were statistically analyzed using SPSS Version 20 to answer three proposed research questions.

With regard to the research questions in this study, since in each stage we intended to analyze the relationship between a three-level dependent variable (Agree/Disagree/Not decided) and a dichotomous independent variable with two levels (public and private English teachers), we made resource to Multinomial Logistic Regression (MLR). In this statistical procedure, the relationship between a non-metric dependent variable and metric or dichotomous independent variables on our intended data (general CM strategies vs. specific CM strategies) could be analyzed in statistical terms. Namely, predicted group membership could first be compared to actual group membership to obtain a measure of classification accuracy.

With regard to the first research question, namely whether there are any differences between English language teachers' strategies in Iranian private language institutes and Iranian public high schools regarding disciplining disruptive behavior in language classes, the overall test of relationship among the independent variables (here school type) defined by the dependent variable (strategy) was first analyzed for each strategy type in two successive stages:

First, model fitting information was obtained for each strategy type using chisquare method for both general (Table 2) and specific teacher strategies (Table 3) for $\mathrm{CM}$ and then for responding to the second and third research questions within significant strategies.

Table 2 shows the results of chi-square estimate for each strategy type within general teacher CM strategy across public and private English language teachers.

Table 2: Model Fitting Information Summary from MLR for each item for General CM items (Section A)

\begin{tabular}{lllc}
\hline $\begin{array}{l}\text { Item } \\
\text { no. }\end{array}$ & Strategy types & \multicolumn{2}{c}{ Likelihood Ratio Test } \\
& & Chi-square & Sig. level \\
\hline $\mathbf{1}$ & $\begin{array}{l}\text { Describing or commenting on } \\
\text { bad behavior }\end{array}$ & 3.440 & 0.17 \\
\hline $\mathbf{2}$ & Rewarding positive behavior & 2.992 & 0.23 \\
\hline $\mathbf{3}$ & Timing out for punishment & 1.316 & 0.51 \\
\hline $\mathbf{4}$ & $\begin{array}{l}\text { Singling out mischievous } \\
\text { student }\end{array}$ & 1.60 & 0.44 \\
& $\begin{array}{l}\text { Exclusion: Sending students } \\
\text { out of class }\end{array}$ & $\mathbf{7 . 2 1}$ & $\mathbf{0 . 0 2}$ \\
\hline $\mathbf{5}$ & & \\
\hline
\end{tabular}




\begin{tabular}{llll}
\hline $\mathbf{6}$ & $\begin{array}{l}\text { Seeking help from higher in } \\
\text { charge staff (school principal) }\end{array}$ & $\mathbf{9 . 8 3}$ & 0.33 \\
\hline $\mathbf{7}$ & $\begin{array}{l}\text { Using anger management } \\
\text { strategies }\end{array}$ & 2.18 & 0.25 \\
\hline $\mathbf{8}$ & $\begin{array}{l}\text { Warning of consequences of } \\
\text { behavior }\end{array}$ & 2.71 & 0.13 \\
\hline $\mathbf{9}$ & $\begin{array}{l}\text { Seeking parent help: Sending } \\
\text { home notes }\end{array}$ & 4.07 & 0.12 \\
\hline $\mathbf{1 0}$ & $\begin{array}{l}\text { Modeling self-regulatory } \\
\text { strategies }\end{array}$ & 4.17 & 0.00 \\
\hline $\mathbf{1 1}$ & $\begin{array}{l}\text { Exclusion: Not letting late } \\
\text { students to class }\end{array}$ & $\mathbf{1 0 . 9 1}$ & 0.11 \\
\hline $\mathbf{1 2}$ & $\begin{array}{l}\text { Paying special attention to } \\
\text { backseat students }\end{array}$ & 4.28 & 0.73 \\
\hline $\mathbf{1 3}$ & Using fixed punishment for all & 0.62 & \\
\hline & &
\end{tabular}

According to Table 2, the probability of the model chi-square just for three items $(5=7.21,6=9.83$ and $11=10.91)$ out of the thirteen items related to general $\mathrm{CM}$ was less than or equal to the level of significance of 0.05 . Then the same procedure was carried out for the second half of the distributed questionnaire (Table 3) regarding specific teacher strategies, which were pertained to language classes (here English).

Table 3: Model Fitting Information Summary from MLR for each item for Specific CM items (Section B)

\begin{tabular}{|c|c|c|c|}
\hline \multirow{2}{*}{$\begin{array}{c}\text { Item } \\
\text { no. }\end{array}$} & \multirow[t]{2}{*}{ Strategy types } & \multicolumn{2}{|c|}{ Likelihood Ratio Test } \\
\hline & & Chi-square & Sig. level \\
\hline 14 & $\begin{array}{l}\text { Punishing plagiarism with } \\
\text { negative points }\end{array}$ & 0.11 & 0.94 \\
\hline 15 & $\begin{array}{l}\text { Using the target language } \\
\text { (here, English) for } \\
\text { reprimanding }\end{array}$ & 9.19 & .01 \\
\hline 16 & $\begin{array}{l}\text { Using negative points for silent } \\
\text { students in group works }\end{array}$ & 3.71 & 0.15 \\
\hline 17 & Student preparation for tasks & 6.09 & 0.04 \\
\hline 18 & $\begin{array}{l}\text { Using nonverbal language for } \\
\text { hinting on bad behavior }\end{array}$ & 6.63 & 0.03 \\
\hline 19 & $\begin{array}{l}\text { Bringing syllabuses to class } \\
\text { for informing students of } \\
\text { lesson stages }\end{array}$ & 5.72 & 0.05 \\
\hline
\end{tabular}




\begin{tabular}{llll}
\hline $\mathbf{2 0}$ & $\begin{array}{l}\text { Promoting respect for cultural } \\
\text { classes }\end{array}$ & 0.13 \\
\hline $\mathbf{2 1}$ & $\begin{array}{l}\text { Counseling with parents about } \\
\text { strategy types }\end{array}$ & 0.39 \\
\hline $\mathbf{2 2}$ & $\begin{array}{l}\text { Checking the decor of the } \\
\text { classroom }\end{array}$ & 1.20 & 0.52 \\
\hline
\end{tabular}

According to Table 3, the probability of the model chi-square just for four items $(15=9.19,17=6.09,18=6.63$ and $19=5.72)$ out of the remaining nine items was less than or equal to the level of significance of 0.05 .

Thus, regarding Tables 2 and 3, the first null hypothesis that there was no significant difference between the model without independent variable(s) and the model with independent variables could safely be rejected just for the specified seven items within general (three strategies) and specific (four strategies) within CM. Interpretation of the results was done using the estimated frequency rates for each general vs. specific teacher strategy type individually. As shown in Table 4, in the second stage for responding to the second and third research questions, the frequency rates for the items with significant likelihood of ratio were closely considered to interpret the results.

Table 4: Frequency Rates for the Statistically Significant Strategy Types per Schools (private and public)

\section{Case Processing Summary}

\begin{tabular}{|c|c|c|c|c|c|c|}
\hline \multirow{3}{*}{$\begin{array}{l}\text { Strategy use per } \\
\text { school types }\end{array}$} & \multicolumn{6}{|c|}{ Cases } \\
\hline & \multicolumn{3}{|c|}{ Private school } & \multicolumn{3}{|c|}{ Public school } \\
\hline & $\frac{\text { Agree }}{\%}$ & $\begin{array}{c}\text { Disagree } \\
\%\end{array}$ & $\frac{\frac{\text { Not }}{\text { decided }}}{\%}$ & $\frac{\text { Agree }}{\%}$ & $\begin{array}{c}\text { Disagree } \\
\%\end{array}$ & $\frac{\begin{array}{c}\text { Not } \\
\text { decided }\end{array}}{\%}$ \\
\hline $\begin{array}{l}\text { Warning or } \\
\text { threatening }\end{array}$ & 42.5 & 50 & 7.5 & 80 & 13.3 & 6.6 \\
\hline $\begin{array}{l}\text { Sending to } \\
\text { principal's office }\end{array}$ & 37.5 & 47.5 & 15 & 80 & 20 & 0 \\
\hline $\begin{array}{l}\text { Not letting in late } \\
\text { students }\end{array}$ & 25 & 62.5 & 12.5 & 73.3 & 20 & 6.66 \\
\hline $\begin{array}{l}\text { Using target } \\
\text { language for } \\
\text { reprimanding bad } \\
\text { behaviors }\end{array}$ & 62.5 & 22.5 & 15 & 20 & 33.3 & 46.6 \\
\hline
\end{tabular}




\begin{tabular}{lcccccc}
\hline $\begin{array}{l}\text { Preparing students } \\
\text { for tasks }\end{array}$ & 62.5 & 17.5 & 20 & 86.6 & 13.3 & 0 \\
\hline $\begin{array}{l}\text { Using nonverbal } \\
\text { language for } \\
\text { warning }\end{array}$ & 62.5 & 15 & 22.5 & 86.6 & 13.3 & 0 \\
\hline $\begin{array}{l}\text { Bringing syllabuses } \\
\text { to class for } \\
\begin{array}{l}\text { informing students } \\
\text { of lesson stages }\end{array}\end{array}$ & 67.5 & 20 & 12.5 & 80 & 0 & 20 \\
\hline
\end{tabular}

As made clear in Table 4, and in line with the second and third research questions, the null research hypotheses on the extent to which teacher strategies were differentiated across (school type) and (strategy kind) for CM, these hypotheses could be safely rejected and the alternative hypothesis only for the significant strategies in the previous stage was accepted.

In the next section, the probable interpretations regarding the estimated frequency rates for general vs. specific strategy kind across school type (private and public) English language teachers at Iranian institutions in our sample respondents is discussed to illuminate what might be involved in the gained findings.

Regarding the last open question as to any other probable strategies the teachers liked to use, since the given responses were too general and in the majority of cases this part of the questionnaire had been left unanswered by the invited teachers, the data relevant to this part could not be explored any further.

\section{RESULTS AND DISCUSSION}

To recap the intended purposes of this exploratory research, we aimed at differentiating strategy taking/selection for managing disruptive behavior in language classes by two groups of English teachers within two diverse educational settings of Iranian private language schools and public high schools. The results of the statistical analyses showed that among the sampled group, only seven strategies could significantly differentiate strategy adoption in the target group; three strategies in general CM and four strategies in specific CM for a language class. First, a brief reference is made for the results gained within the general CM teacher strategies category.

In response to the second research question regarding general teacher strategies for $\mathrm{CM}$, as Table 3 clearly indicated, among general CM strategies, three strategies: a) exclusion (dismissing the students from the class ( $\mathrm{p} \geq .02), b)$ not admitting students into the class as punishment for misconduct ( $\mathrm{p} \geq .00)$, and $\mathrm{c}$ ) seeking help from higher staff members in charge ( $\mathrm{p} \geq .00)$ were statistically significant in differentiating between high school language teachers and institute language teachers practices. 
In order to find the tendency of these two groups of teachers towards using more robust strategies, frequency rates method was used. As Table 5 indicated, $80 \%$ of high school language teachers tended to warn or threaten students of consequences of misconduct in classroom, while only $42.5 \%$ of institute teachers liked to use this strategy in their classes. This may be viewed as more imposing and high-handed behavior on the part of high school language teachers in dealing with students' misbehavior. This pointed to the use of more assertive strategies towards harsh mannerism in treating misbehavior, which is usual in more formal educational settings, but is less likely to occur in private language institutes. This was also particularly striking in the case of seeking help from more powerful authorities, such as the school principal in dealing with misconduct $(80 \%$ for public school language teachers vs. $37.5 \%$ for private school language teachers). Such strategies, which may be effective in dealing with misbehavior in formal settings, might, on the other hand, appear to be in stark violation of democratic educational policies, which to our view might deleteriously reduce students' motivation to learn in the long run. It could, therefore, lead us to believe that motivational factors for attending language classes in private language institutes is optimally conducive to learning compared with the way such issues are manipulated in Iranian public high school settings. Certainly, this was not to be interpreted advocating giving the students free rein to behave as like. However, it seemed that in line with the democratic guidelines for education stipulating decision making to be open to the learners, and the learners to have equal rights with their teachers, such a tendency on the part of the sampled teachers in this study was eyecatching. In democratic schools, staff members have meetings with all the students, and should any conflicts arise with regard to pedagogical issues, the problem is negotiated, and all voices should be heard, 'A democratic authority in the school, be it a teacher, administrator, coach, counselor, or teacher aid, is led by persuasion and negotiation' (Knight \& Pearl, 2000: p. 206). Y1ldız and Doğan (2015; cited in Sadik \& Yalcin, 2018) asserted that such governed behavior on the part of the learners is characterized with knowing each other in order to respect one another and internalized the social rules and relevant affective skills. In Zuckerman's study (2007, 2009), nonverbal hinting cues such as 'looking', 'questioning' and 'naming' were reported as more effective than direct warning or threatening.

Regarding the third research question pertaining strategy type differentiation between the two public schools and private English language institute teachers' specific strategy adoption for a language class, we interpreted estimated frequency rates in Table 5 for the last four items pertained to specific strategy type specifically for a language class. In the specific strategy area for CM domains, four strategies were telling of a significant difference on certain grounds between our target groups of teachers, including (a) using the target language to comment on the students' misbehavior ( $\mathrm{p} \geq .01)$, (b) preparing students for tasks ( $\mathrm{p} \geq .04)$, (c) using nonverbal language for warning ( $\mathrm{p} \geq .03)$, and (d) bringing syllabus to class ( $\mathrm{p} \geq .05)$. On the whole, $62.5 \%$ of the private school English teachers indicated that they tended more to use English language to reprimand students and reminded them to show appropriate behavior in class, while this tendency being extremely low for the public school teachers (20\%). This marked difference could be ascribed to the learners' proficiency levels, though. Nevertheless, since in private language schools, an immersion program towards the target language (here English) is generally maintained, therefore the teachers tended to use English rather than Persian in dealing with disruptive behavior 
by the students. However, this preferred tendency should not be immediately interpreted as the private school teachers' preferred using of English as being essential on pedagogical grounds. They might have been opted for the teachers to maintain English-only classes on emotional grounds, perhaps contrary to their personal preferences. It might seem reasonable that using the target language might not be as effective as the students' first language by the language teachers in Iranian public high schools in treating misbehavior of the students probably since the learners might not be able to understand what it is all about for which they are warned due to their diverse proficiency levels. This had to be further inquired from the sampled teachers, though. What seemed obvious was that public language teachers in our target teachers had preferred either not to answer by opting for $46 \%$ (undecided) or marking 'disagree' option. All the same, further research needs to be done to investigate the actual reasons behind some teachers' inclination to use the students' first language rather than the target language. There should be involved a multitude of reasons besides emotional motives.

Regarding the second significant type of strategy, that is, using preparatory procedures in task management issues, in all, 80.6\% of the public school language teachers declared that they used preparatory procedures when using language tasks, with fewer private language institute teachers $(62.5 \%)$ declaring it to be the case with them. On the surface, this could point to, among other things, the public school language teachers' showing greater pedagogical knowledge than private institute teachers in using strategies that are more effective in their classes by making resource to such preparatory procedures for proper tasks. Evidently, having graduated from university, a large number of Iranian teachers tend to be indulged in private language institutes. In some cases, these graduates hold non-TEFL degrees, such as Translation Studies or English Literature. It seems that in such cases, some pedagogical training courses might be required in order for these novice teachers to acquire some pedagogical skills to become effective teachers. To be sure, this per se cannot be interpreted as less effective strategies being predominant in private language institutes, but it can be taken as an indication that as far as L2 teacher education standards in our Iranian settings are concerned, optimal teacher training programs are required for these novice teachers to find their bearings in class management skills in the same way as the more experienced teachers do. This issue is rarely taken seriously as far as our experience is concerned in holding such courses at language schools in Iran. There are some courses in Teaching English to Speakers of other languages (TESOL) held in some language schools in large cities like Tehran, Mashhad, Shiraz and Isfahan, which some language school managers attend, but they are not compulsory for regular language teachers.

The last two strategy types were also statistically significant in their effectiveness as decided by the sampled teachers, with $86.6 \%$ of public school teachers and $62.5 \%$ of private institute language teachers asserting that they liked to use nonverbal strategies, such as using body language, in managing their classes. This issue might be attributed to more accountability required of public school teachers in managing classes, which is not as rigorously applied to informal settings, as the gained data designate. This was also the case with 'Bringing syllabuses to class for informing students of lesson stages', which had been implemented more rigorously by public school teachers (80\%) compared with private language schoolteachers $(67.5 \%)$ ). This 
situation among many other cases point to more effective $\mathrm{CM}$ strategies regarding disciplinary issues used by public school teachers compared with private institute teachers in their class management $(\mathrm{CM})$ practices. It should be borne in mind, however, that in private institute settings the circumstances for learning language may be of a drastically different nature. It is possible that due to more limited facilities available to private institute teachers in Iranian language schools, it may have more to do with the availability of institutional services to the teachers than their personal preferences or skills. In the end, in order to show how and why certain strategies could be dictated via institutional constraints, a brief review of the educational policies at private language schools in Iran is given to show how shortage of facilities rather than lack of pedagogical skills on the part of language teachers in private institutes can hamper adopting appropriate strategies in instilling and maintaining discipline in private languages classes.

\section{IMPLICATIONS OF THE STUDY}

In Iranian educational settings, language institutes are considered informal and private or semi-private and directed by language teachers or university professors usually having their own language schools along with their affiliated educational organizations, affiliated with the Iranian Ministry of Education (MoE) or the Ministry of Science, Research \& Technology (MSRT), Social Security Organization (SSO), etc. In the current situation, there are some accredited language institutes that are governed under the direct supervision of some other organizations, including the Ministry of Culture and Islamic Guidance (MSIG) and the Revolutionary Guards Corps (RGC). Although all the educational activities of these language institutes are for the most part governed by the Iranian MoE, the management and disciplinary procedures might be carried out using various strategies depending on the license issuing company or organization. For example, in the language institutes under the direct supervision of $\mathrm{MoE}$, strict rules of conduct are imposed, including the segregation of male and female classes, observing Islamic dress code (hijab), and some other religious rites, imposed more strictly on both the learners and the teachers. Another source of variation which may be influential here concerns the managers of the institutes. The managers are required to exert all their efforts to apply similar conditions in implementing educational goals compared with formal educational settings; however, their strategies might not be in agreement with all the established rules governing formal educational settings. As an example, in recruiting language teachers, the institute managers are at times indirectly influenced by their own individual mannerism in having personal clerical relationships with some teachers to continue cooperation with them in applying the institutes' educational programs to the best possible way. To the best experience of the present authors of this research, many language teachers active in language institutes who have freshly graduated from college and are seeking temporary job positions, might not be fully familiar with general pedagogical skills. Such practices in teacher employment could also be influential in how the institute is governed, since the language teachers are the main activists and manipulators of higher order disciplinary matters. In some Iranian language institutes, classes are held in rented buildings not suitable for educational purposes due to some financial constraints. Their classes are usually held in small rooms, and the buildings are located in busy areas with lots of noise pollution. Class size and noisy nature of the selected locations for private 
language schools could indirectly lead to some distraction during class hours. This could probably have some effects on the strategies related to general class management (CM) adopted by language teachers. From standpoints of some CLT proponents as mentioned by Butler (2011), this could bring elements of noise in the classroom. Still, a lot of other unauthorized behavior resulting from miscommunication could arise during teacher-student interactions.

\section{CONCLUSION}

In the end, this finding can only indicate a partial view of the factors involved in the two educational settings and the results must be authenticated with further research studies. Due to many constraints in accessing more language teachers at public schools because of the low number of English teachers who participated in this study, the gained results might not show a comprehensive picture of the investigated issues. Still, more research studies can be done on this issue to discover other hidden aspects of the topic as may have been left unnoticed in the present study. One more limitation in this study which might require us to be circumspect about generalizing the results concerns the respondents' varying university educational qualifications. However, we considered teaching experience and gender to be more pertinent in treating and disciplining disruptive behavior than the academic qualification of the respondents. Future researchers may decide to examine this pertinent variable as well.

\section{REFERENCES}

Ashton, K. (2018). Exploring teacher views of multi-level language classes in New Zealand secondary schools. Teaching and Teacher Education, 69, 104-118.

Brown, H. D. (2001a). Statistics Corner. Questions and answers about language testing statistics: Can we use the Spearman-Brown prophecy formula to defend low reliability? Shiken: JALT Testing \& Evaluation SIG Newsletter, 4(3), 7-9.

Brown, H. D. (2001b). Teaching by principles. White Plains, NY: Pearson Education.

Brown, H. D. (2007). Teaching by principles: An interactive approach to language pedagogy (3rd Ed.). Englewood Cliffs, New Jersey: Prentice Hall Regents.

Butler, Y. G. (2011). The implementation of communicative and task-based language teaching in the Asia-Pacific region? Annual Review of Applied Linguistics 31, 36-57.

Cox, C. B., \& Boyson, R. (Eds.). (1975). Black papers: the right for education. London: Dent.

De Jong, R., van Tartwijk, J., Wubbles, T., \& Verloop, N. (2013). Student teachers' discipline strategies: Relations with self-images, anticipated student responses and pupil control orientation. Educational Studies, 39(5), 582-597.

DorBremme, D.W. (1990). Contextualization cues in the classroom: Discourse regulation and social control functions. Language in Society, 19(3), 379-402.

Dreikurs, R., Cassel, P., \& Ferguson, E. D. (2004). Discipline without tears: How to reduce conflict and establish cooperation in the classroom (Rev. ed.). Mississauga, Ontario: Wiley.

Education Bureau. (2014). Student Guidance and Discipline Services. Available at http://www.edbi.gov.hk/en/student-parents/student-guidance-disciplineservices/overview/index.html.

George, D., \& Mallory, P. (2003). SPSS for Windows step by step: A simple guide and reference. 11.0 update (4th Ed.). Boston: Allyn \& Bacon.

Glock, S., \& Kleen, H. (2017). Gender and student misbehavior: Evidence from implicit and explicit measures. Teaching and Teacher Education, 67, 93-103. 
Jinot, B. L. (2018). The Causes of a Lack of Discipline among Secondary School Learners in Mauritius. Mediterranean Journal of Social Sciences, 9(1), 35.

Johnston, B. (2008). Values in English Language Teaching. UK: Lawrence Erlbaum.

Kang, D. M. (2013). EFL teachers' language use for classroom discipline: A look at complex interplay of variables. System, 41(1), 149-163.

Khodarahmi, E., \& Motallebi Nia, Z. (2014). EFL Teachers` classroom discipline strategies and learners' willingness to communicate in English inside the classroom. International Conference on Current Trends in ELT, Procedia - Social and Behavioral Sciences 98, 976-981.

Knight, P., \& Pearl, A. (2000). Democratic Education and Critical pedagogy. The Urban Review, 32(3), 197-226.

Kounin, J. S. (1970). Discipline and group management in classrooms. New York: Holt, Rinehart and Winston.

Lefstein, A., Trachtenberg-Maslaton, R., \& Pollak, I. (2017). Breaking out of the grips of dichotomous discourse in teacher post-observation debrief conversations. Teaching and Teacher Education, 67, 418-428.

Lewis, R., Romi, S., Qui, X., \& Katz, Y. J. (2008). Students' reaction to classroom discipline in Australia, Israel, and China. Teaching and Teacher Education, 24, 715-724.

Markham, P.L. (1987). Classroom management in the secondary school foreign language class. System, 15(2), 217-220.

Margutti, P. (2006). 'Are you human beings?' Order and knowledge construction through questioning in primary classroom interaction. Linguistics and Education, 17(4), 313-346.

Margutti, P., \& Marsh, A. P. (2011). The interactional management of discipline and morality in the classroom: An introduction. Linguistics and Education, 22, 305-309.

Martin, D. L. (1977). Your praise can smoother learning. Learning, 5(6), 43-51.

Mollica, A., \& Nuessel, F. (1997). The good language learner and the good language teacher: A review of the literature. Mosaic, 4, 1-16.

Oplatka, I., \& Atias, M. (2007). Gendered views of managing discipline in school and classroom. Gender and Education, 19(1), 41-59.

Rahimi, M., \& Hosseini, K. F. (2012). EFL teachers' classroom discipline strategies: the students' perspective. Procedia - Social and Behavioral Sciences, 31, 309 - 314. DOI:10.1016/j.sbspro.2011.12.060.

Rahimi, M., \& Asadollahi, F. (2012). On the relationship between Iranian EFL teachers' classroom management orientations and teaching style. Procedia-Social and Behavioral Sciences, 31, 49-55.

Rose, L. C. \& Gallup, A. M. (2004). Gallup poll of the public's attitudes toward public schools. The 36th Annual Phi Delta Kappal Available online: www.pdkintl.org/kappan/k0409pol.htm\#exec.

Sadik, F., \& Yalcin, O. (2018). Examination of the Views of High School Teachers and Students with Regard to Discipline Perception and Discipline Problems. Journal of Education and Training Studies, 6(2), 97-113.

Soares, D. (2007). Discipline problems in the EFL class: Is there a cure? Profile, 8, 41-58.

Strack, F., \& Deutsch, R. (2004). Reflective and impulsive determinants of social behavior. Personality and social psychology review, 8(3), 220-247.

Sun, R. C. (2015). Teachers' experiences of effective strategies for managing classroom misbehavior in Hong Kong. Teaching and Teacher Education, 46, 94-103.

Ur, P. (1996). A course in language teaching, theory and practice. Cambridge: Cambridge University Press.

Woolfolk Hoy, A., \& Weinstein, C. S. (2006). Studentse and teachers' perspectives on classroom management. In C. Evertson \& C. S. Weinstein (Eds.). Handbook for classroom management: Research, practice, and contemporary issue (pp. 181-220). Mahwah, NJ: Lawrence Erlbaum.

Zuckerman, J. T. (2007). Classroom management in secondary schools: A study of student teachers' successful strategies. American Secondary Education, 4-16.

Zuckerman, J. T. (Ed.). (2009). From Lesson Plans to Power Struggles, Grades 6 12: Classroom Management Strategies for New Teachers. Corwin Press 


\section{Appendix A}

What follows is a questionnaire on teacher classroom management strategies in language institutes. It is in two parts including A) general class management and B) language classroom management items. You are requested to kindly give your idea on each item ranging from 'strongly agree' to 'strongly disagree'. What is meant by misbehavior in this research is whatever disruptive and unauthorized behavior that might directly disturb your class normal order like being late for class, cheating in exams, coming to class without a textbook or necessary materials, shouting loud, talking with friends, inattention etc. The purpose is to check your strategies as a teacher in controlling a language class. I would really like to thank you for agreeing to contribute to this end. This contribution is quite confidential, anonymous, and totally voluntary. However, I am willing to give you a summary of the results if you would like to have it. If so, or in case of any query, please contact me at ...

Years of experience: $5-1$

10

20

Gender: Male

Femal

\section{A. General Class Management:}

1. I describe or comment on bad behavior in my class rather than why misbehavior had happened.
A) Strongly agree
B) Agree
C) no idea
D) Disagree
E) Strongly disagree

2. I reward targeted positive behaviors with incentives like stickers, extra points, etc.
A) Strongly agree
B) Agree
C) no idea
D) Disagree
E) Strongly disagree

3. For aggressive behavior I use 'Time Out' (Time Away) to calm down my students.
A) Strongly agree
B) Agree
C) no idea
D) Disagree
E) Strongly disagree

4. I may single out a student or a group of students for misbehavior.
A) Strongly agree
B) Agree
C) no idea
D) Disagree
E) Strongly disagree

5. I warn or threaten to send a student out of classroom if s/he doesn't behave well in class.
A) Strongly agree
B) Agree
C) no idea
D) Disagree
E) Strongly disagree

6. I send my students to the principal's office for aggressive or destructive misbehavior.
A) Strongly agree
B) Agree
C) no idea
D) Disagree
E) Strongly disagree

7. I sometimes use anger management strategy for self (e.g., deep breaths, positive selftalk) to calm down myself.
A) Strongly agree
B) Agree
C) no idea
D) Disagree
E) Strongly disagree

8. I like to warn of consequences for misbehavior (e.g., loss of privileges, sending students out of the class, failing ...).
A) Strongly agree
B) Agree
C) no idea
D) Disagree
E) Strongly disagree

9. To report problematic behavior to parents, I send home notes (or frowny faces).
A) Strongly agree
B) Agree
C) no idea
D) Disagree
E) Strongly disagree

10. Modeling self-regulation strategies for students is one of my strategies in controlling my class.
A) Strongly agree
B) Agree
C) no idea
D) Disagree
E) Strongly disagree 
11. If a student comes late to class for several times, I do not let him/her to class.
A) Strongly agree
B) Agree
C) no idea
D) Disagree
E) Strongly disagree

12. I pay special attention to those students who sit at the back of the classroom.
A) Strongly agree
B) Agree
C) no idea
D) Disagree
E) Strongly disagree

13. I have fixed punishments for all students if they misbehave in class and distract my lessons.
A) Strongly agree
B) Agree
C) no idea
D) Disagree
E) Strongly disagree

\section{B. Language Class Management:}

14. In response to students' unauthorized behavior like copying assigned writings from somewhere (plagiarism) I try to punish them with negative points.
A) Strongly agree
B) Agree
C) no idea
D) Disagree
E) Strongly disagree

15. I reprimand unauthorized behavior in the target language (English).
A) Strongly agree
B) Agree
C) no idea
D) Disagree
E) Strongly disagree

16. On giving group work activities to my students, I try to give negative points to silent students or those who speak Farsi.
A) Strongly agree
B) Agree
C) no idea
D) Disagree
E) Strongly disagree

17. I prepare my class for transitions to the next activities with predictable routines that they are familiar with.
A) Strongly agree
B) Agree
C) no idea
D) Disagree
E) Strongly disagree

18. I use nonverbal signals to redirect a student who is disengaged in class tasks instead of warning in English.
A) Strongly agree
B) Agree
C) no idea
D) Disagree
E) Strongly disagree

19. I distribute a language syllabus with purposes among students at the beginning of the term to warn them of various stages of the lesson, exam times, expectations, etc.
A) Strongly agree
B) Agree
C) no idea
D) Disagree
E) Strongly disagree

20. I promote respect for cultural differences of L1 with L2 in my classroom if any clashes arise.
A) Strongly agree
B) Agree
C) no idea
D) Disagree
E) Strongly disagree

21. I talk with parents about special preparatory activities to do with their child at home.
A) Strongly agree
B) Agree
C) no idea
D) Disagree
E) Strongly disagree

22. I change the décor and layout of my class with English items to prevent boredom and probable misbehavior among students.
A) Strongly agree
B) Agree
C) no idea
D) Disagree
E) Strongly disagree 
In case you have any other strategies in controlling your class as to 'misbehavior' please do not hesitate to write your comments below. Thank You!

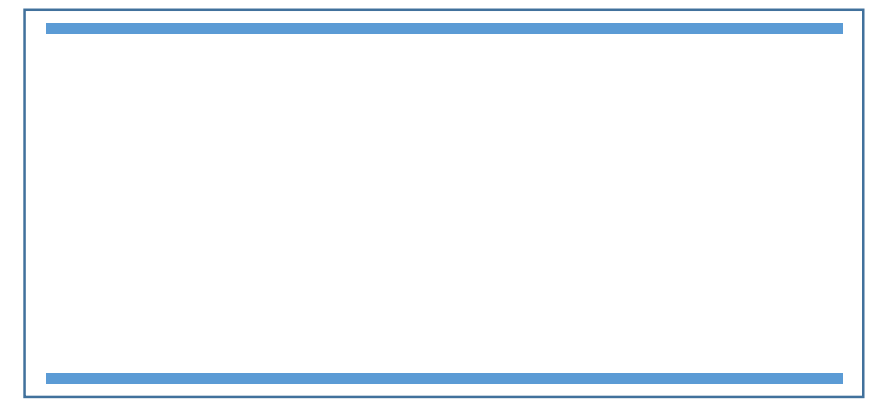

AUTHORS

Marjan Vosoughi is currently a full-time faculty member of Islamic Azad University of Sabzevar, Iran. She holds a PhD in TEFL from Al-Zahra University of Tehran, Iran. She has various international publications in Applied Linguistics. Her areas of interest are language assessment, psycholinguistics, discourse analysis and materials designing for literacy aspects.

Zohreh Nafissi is a faculty member of the English Language Dep't at Alzahra University, Tehran, Iran, where she served as the Head of Dep't for 3 years. She received her MA and MPhil from Glasgow University, Scotland, and her PhD in TEFL from Allameh Tabatabai University. She has been teaching postgraduates for the past 5 years and presented over 20 papers at national and international conferences. Her main research interests are ESP, Teacher Education, Learner Identity, Linguistic Imperialism, etc. 